\title{
Arginine 109 to glutamine mutation in a girl with ornithine carbamoyl transferase deficiency
}

\author{
Sandra Strautnieks, Paul Rutland, Sue Malcolm
}

\begin{abstract}
We studied DNA from 29 families with at least one member with ornithine carbamoyl transferase (OCT) deficiency and have found a mutation in the TaqI site within exon 5 of the OCT gene in a female presenting at the age of 21 months. Hybridisation with site specific oligonucleotides shows that the mutation is a $C$ to $T$ substitution resulting in a glutamine for arginine substitution at amino acid 109.
\end{abstract}

Ornithine carbamoyl transferase deficiency is an $\mathrm{X}$ linked disorder caused by mutation of the urea cycle enzyme ornithine carbamoyl transferase. Heterozygous females have very variable manifestations, some being virtually asymptomatic while others have severe protein intolerance and recurrent hyperammonaemia. ${ }^{1}$ The reason for this variation is not known although it is usually assumed that it is a result of unequal $\mathrm{X}$ inactivation. A survey of mutations found in symptomatic females is needed to clarify the variation in clinical symptoms.

A number of mutations have been defined in males with OCT deficiency. These include deletions and point mutations. ${ }^{2-7}$ Of particular interest is the finding of several independent mutations having arisen at codon 109 within a $T a q$ I restriction enzyme site. ${ }^{458}$ Mutations of $\mathrm{C}$ to $\mathrm{T}$ at this position in the coding strand change arginine to a stop $\operatorname{codon}^{45}$ and arginine to glutamine when the change occurs on the complementary DNA strand. ${ }^{5}$ Cell transfection studies confirmed that this latter change abolishes enzyme activity. ${ }^{8}$ The arginine to stop mutation has already been found in a mildly affected female patient ${ }^{4}$ and we now report the other, arginine to glutamine, change arising independently for a second time, in this case in an affected female.

Mothercare Unit of Paediatric Genetics, Institute of Child Health, 30 Guildford Street, London WC1N 1 EH.

S Strautnieks, P Rutland, S Malcolm

Correspondence to Dr Malcolm.

Recieved for publication 28 January 1991.

Revised version accepted for publication 16 May 1991.

\section{Materials and methods CLINICAL DETAILS}

The female proband is $3 \frac{1}{2}$ years of age and presented at the age of 21 months with developmental delay (around the 9 to 10 month level) and poor growth $(-3.62 \mathrm{SD})$. Increased urine glutamine and orotic acid confirmed OCT deficiency. On a low protein diet, sodium benzoate, and arginine she has done well and her growth has caught up somewhat (now being only $-1.96 \mathrm{SD}$ ). At $3 \frac{1}{2}$ years of age her development is now borderline normal. There was no previous family history. Chromosomal analysis was not performed.

We examined DNA from a further 28 families with at least one member, male or female, manifesting OCT deficiency, who had been referred to the Institute of Child Health for DNA testing for carrier detection or prenatal diagnosis.

\section{OLIGODEOXYRIBONUCLEOTIDE SYNTHESIS}

Oligonucleotide primers and probes were synthesised on an Applied Biosystems 38IA DNA synthesiser.

\section{TaqI RESTRICTION ENZYME ANALYSIS}

DNA was prepared from the nuclei of peripheral leucocytes by guanidinium hydrochloride extraction, ${ }^{9}$ digested with $T a q I$ according to the manufacturer's instructions (NBL), and the fragments separated by electrophoresis on a $\mathbf{0 . 8 \%}$ agarose gel. After denaturation of the gel with $0.4 \mathrm{~mol} / 1 \mathrm{NaOH}$, $1.5 \mathrm{~mol} / 1 \mathrm{NaCl}$, the DNA was blotted directly onto Hybond $\mathrm{N}+$ (Amersham International) and fixed by rinsing with $0.4 \mathrm{~mol} / 1 \mathrm{NaOH}$ followed by two washes with $2 \times$ SSC.

\section{HYBRIDISATION PROBE}

The probe used was a $1.5 \mathrm{~kb}$ human cDNA insert isolated from Nuseive-GTG agarose or whole plasmid and labelled by random hexanucleotide primer extension with a ${ }^{32}$ PdCTP. Prehybridisation and hybridisation were carried out in $10 \times$ Denhardt's solution, $4 \times$ SSC, $50 \mu \mathrm{g} / \mathrm{ml}$ sonicated salmon sperm DNA, and $0.1 \%$ SDS for 16 hours each. Filters were washed for $3 \times 20$ minutes in $3 \times$ SSC, 
$0 \cdot 1 \%$ SDS at room temperature followed by a final wash in $0.5 \times$ SSC, $0.1 \%$ SDS for 30 minutes at $65^{\circ} \mathrm{C}$.

The probe covers exons 1 to 10 and recognises TaqI restriction fragments of $4 \cdot 6,3 \cdot 8,2 \cdot 7,1 \cdot 9,1 \cdot 8$, $1 \cdot 4,0.9$, and $0.8 \mathrm{~kb}$.

POLYMERASE CHAIN REACTION (PCR) ANALYSIS Exon 5 (for the proband's family) and exon 1 (for an affected subject or known carrier from each family) were amplified using PCR. Primers for exon 5 have been previously reported. ${ }^{4}$ Exon 1 primers were, on the $5^{\prime}$ side, 5'TCACTGCAACTGAACACATTTCTTA3' and, on the $3^{\prime}$ side, 5'CCTAAATCAAACCCAAGTCTCTGACC3'.

The sequences were obtained from Dr M Grompe (personal communication).

Genomic DNA ( $500 \mathrm{ng}$ ) in a total volume of $100 \mu \mathrm{l}$ was denatured at $94^{\circ} \mathrm{C}$ for four minutes; 2.5 units of TaqI polymerase (Promega) were added and the mix held at $50^{\circ} \mathrm{C}$ for five minutes and then 30 cycles of one minute at $72^{\circ} \mathrm{C}$, one minute at $94^{\circ} \mathrm{C}$ and 30 seconds at $50^{\circ} \mathrm{C}$ for exon 5 and one minute at $72^{\circ} \mathrm{C}$, one minute at $94^{\circ} \mathrm{C}$, and 30 seconds at $56^{\circ} \mathrm{C}$ for exon 1.

\section{TaqI RESTRICTION ENZYME ANALYSIS OF PCR PRODUCTS}

Twenty microlitres of each amplified product were digested with $T a q \mathrm{I}$ according to the manufacturer's instructions (NBL) and visualised by electrophoresis in $4 \%$ Nuseive-GTG-agarose gels and ethidium bromide staining.

\section{ALLELE SPECIFIC DETECTION OF MUTATION}

Sixty microlitre samples of amplified exon 5 from the proband's family were denatured with $540 \mu$ l of $0.4 \mathrm{~mol} / 1 \mathrm{NaOH}$ for 15 minutes before loading $100 \mu \mathrm{l}$ into the wells of a Minifold Tm filtration manifold (Schleicher and Schuell) containing a Hybond $\mathrm{N}+$ membrane presoaked in $2 \times$ SSC. The wells were washed with $20 \times$ SSC and filters fixed in $0.4 \mathrm{~mol} / 1 \mathrm{NaOH}$.

Three identical blots were prepared. One was hybridised with the wild type oligodeoxyribonucleotide probe as described in Hata $e t a l^{4}$ and the other two with the two possible mutant sequences. All probes were end labelled with gamma ${ }^{32} \mathrm{P}$ deoxyadenosine triphosphate. Blots were hybridised for 16 hours at $47^{\circ} \mathrm{C}$ before washing three times in $3 \times$ SSC, $0.1 \%$ SDS at room temperature and once at either $53^{\circ} \mathrm{C}$ (mutant probe hybridisation) or $57^{\circ} \mathrm{C}$ (wild type probe hybridisation) for 30 minutes before autoradiography for 16 hours.

\section{Results}

TaqI RESTRICTION ENZYME ANALYSIS

A preliminary analysis of 29 patients was carried out using Southern blotting. DNA from seven male and 22 female patients was digested with $T a q I$ and probed with the CDNA probe for OTC. A new band at $3.4 \mathrm{~kb}$ was observed in the proband. No such band was observed in her mother. This band would correspond to a band predicted if the TaqI restriction site normally giving rise to bands 1.8 and $1.6 \mathrm{~kb}$ within exon 5 were mutated. Mutations of the TaqI sites in exons 3 and 9 would also give altered bands, but none such was observed. Only one other altered band was observed after TaqI digestion. This was found in a mother and affected son but must have arisen as the result of the creation of a new TaqI site and its origin remains to be discovered.

\section{PCR ANALYSIS OF EXON 1}

The polymerase chain reaction was used to amplify exon 1 from all 29 patients, as Southern blotting does not readily detect the change in the TaqI site found in exon 1. All amplified bands were digested with TaqI, the resulting products separated on Nuseive agarose gels and visualised by ethidium bromide staining (fig 1). In each case the $217 \mathrm{bp}$ amplification product was digested to a band of 172 bp showing that there were no mutations at the TaqI site in this exon. The other $45 \mathrm{bp}$ band was too small to detect.

\section{PCR ANALYSIS OF EXON 5}

Genomic DNA from the proband and her mother was amplified using primers specific for exon 5 . TaqI digests of the amplified products showed two bands in the case of the proband (fig 2), the expected digestion product of $121 \mathrm{bp}$ from the unaffected X chromosome and an undigested fragment of $156 \mathrm{bp}$ from the other $\mathrm{X}$ chromosome, confirming that the TaqI site has been mutated. Again the other digestion product of $35 \mathrm{bp}$ was too small to detect.

\section{DETECTION OF POINT MUTATION USING ALLELE} SPECIFIC OLIGONUCLEOTIDE HYBRIDISATION

The amplified exon 5 products from the proband and her mother were tested for both predicted $\mathrm{C}$ to T mutations by hybridisation to radiolabelled oligonucleotides corresponding to the sense strand of the normal sequence, and to the sense strands of both mutations. The proband showed clear hybridisation to the normal oligonucleotide but with reduced intensity, as expected for a heterozygote, and to the oligonucleotide corresponding to the arginine to glutamine change (fig 3 ). Her mother showed only hybridisation to the normal sequience. 
$\begin{array}{llllll}1 & 2 & 3 & 4 & 5 & 6\end{array}$

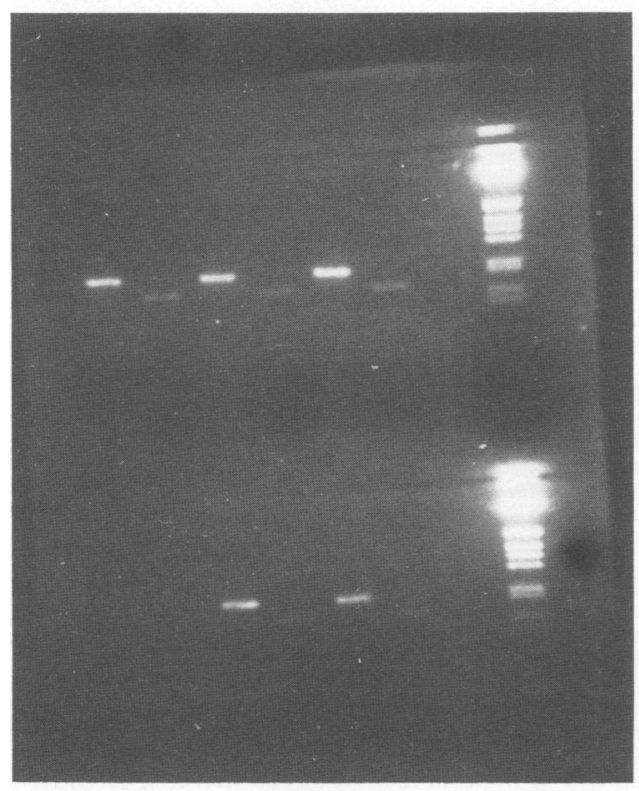

$\begin{array}{llllll}7 & 8 & 9 & 10 & 11 & 12\end{array}$

Figure 1 PCR amplification products of exon 1 digested with TaqI. Tracks 1, 3, 5, 9, and 11 undigested product. Tracks $2,4,6,10$, and 12 samples digested with TaqI. Tracks 7 and 8 blanks. The band size is reduced from $217 b p$ to 172 bp when the TaqI site is present. The $45 \mathrm{bp}$ band is too small to detect.

\section{Discussion}

The coding sequence for ornithine transcarbamylase contains four restriction enzyme sites for TaqI. Systematic studies in other diseases, both $\mathrm{X}$ linked and autosomal, show that the dinucleotide ${ }^{5} \mathrm{CpG}^{3}$ is particularly prone to mutation to ${ }^{5} \mathrm{TpG}^{3^{\prime}}$. Examples have been found in the analysis of the factor IX gene in haemophilia $\mathrm{B}^{1011}$ and the phenylalanine hydroxylase gene in phenylketonuria. ${ }^{12}$ The reason for this is believed to be deamination of methyl $\mathrm{C}$ to form $\mathrm{T}$, followed by repair of the resulting $G$.T mismatch to A.T. As the sequence is symmetrical this can happen in either strand resulting in $C$ to $T$ or $G$ to $A$. $A$ small proportion of $\mathrm{CpG}$ sequences will fall within TaqI sites (recognition site TCGA) and may be directly detectable on Southern blots. The mutation reported here falls within that class. However, the mutation within exon 1 is difficult to detect because of coincidence of band sizes. TaqI digestion of PCR amplified exon products provides a quick and clear screening method.

We have examined $29 \mathrm{X}$ chromosomes giving rise to OCT deficiency at four TaqI sites. We have only 
found one mutation and have found no deletions in eight male samples analysed.

A further $15 \mathrm{CpG}$ sites $^{13}$ are found within the OCT coding region. ${ }^{4}$ They remain to be screened. Five other independent mutations in OCT males have been reported. ${ }^{37}$ They were initially detected either by chemical mismatch cleavage of $\mathrm{mRNA}^{3}$ or by denaturing gradient gel electrophoresis. ${ }^{7}$ Two of the five are produced by mutations within CpG dinucleotides.

This report describes the second mutation found in a female patient. So far they both reproduce mutations found in severely affected males. Further reports are awaited in order to deduce whether the severity in females is connected in any way with the mutation or whether the proportion of $\mathrm{X}$ inactivation is the only critical factor.

As the patient's mother showed no alteration within her TaqI site in exon 5 it is very likely that the patient represents a new mutation. However, a small possibility of mosaicism within the germ cells of the mother remains ${ }^{2}$ and she could be offered prenatal diagnosis based on PCR amplification of exon 5 and TaqI digestion if required.

We wish to thank the Child Health Research Trust for financial support. SS holds an MRC HGMP studentship. We would like to thank Dr Marcus Grompe for kindly providing sequence information in advance of publication, Dr Christine Garrett for referring the patient for genetic counselling, Dr A J
Cronin for providing clinical details, and Dr James Leonard for help and advice.

1 Batshaw ML, Msall M, Beaudet AL, et al. Risk of serious illness in heterozygotes for ornithine transcarbamylase deficiency. I Pediatr 1986;108:236-41.

2 Maddalena A, Sosnoski DM, Berry GT, et al. Mosaicism for an intragenic deletion in a boy with mild ornithine transcarbamylase deficiency. $N$ Engl $f$ Med 1988;319:999-1003.

3 Grompe M, Muzny DM, Caskey CT. Scanning detection of mutations in human ornithine transcarbamaylase by chemical mismatch cleavage. Proc Natl Acad Sci USA 1989; 86:5888-92.

4 Hata A, Setoyama C, Shimada K, et al. Ornithine transcarbamylase deficiency resulting from a $\mathrm{C}$ to $\mathrm{T}$ substitution in exon 5 of the ornithine transcarbamylase gene. Am 7 Hum Genet 1989;45:123-7.

5 Maddalena A, Spence JE, O'Brien WE, et al. Characterisation of point mutations in the same arginine codon in three unrelated patients with ornithine transcarbamylase deficiency. F Clin Invest 1988;82:1353-7.

6 Rozen R, Fox J, Fenton WA, et al. Gene deletion and restriction fragment length polymorphisms at the human ornithine transcarbamylase locus. Nature 1985;313:815-7.

7 Finkelstein JE, Francomano CA, Brusilow SW, et al. Use of denaturing gel electrophoresis for detection of mutation and prospective diagnosis in late onset ornithine transcarbamylase deficiency. Genomics 1990;7:167-72.

8 Lee JT, Nussbaum RL. An arginine to glutamine mutation in residue 109 of human ornithine transcarbamylase completely abolishes enzymatic activity in Cosl cells. $f$ Clin Invest 1989;84:1762-6.

9 Jeanpierre $M$. A rapid method of purification of DNA from blood. Nucleic Acids Res 1987;15:9611.

10 Green PM, Bentley DR, Mibashan RS, et al. Molecular pathology of haemophilia B. EMBO f 1989;8:1067-72.

11 Koeber DD, Bottema CDK, Ketterling RP, et al. Mutations causing haemophilia $B$ : direct estimate of the underlying rates of spontaneous germ-line transitions, transversions, and deletions in a human gene. Am $\mathcal{F}$ Hum Genet 1990;47:202-17.

12 Abadie V, Lyonnet S, Maurin N, et al. CpG dinucleotides are mutation hot spots in phenylketonuria. Genomics 1989;5:936-9.

13 Hata A, Tsuzuki T, Shimada K, et al. Structure of the human ornithine transcarbamylase gene. $\mathcal{f}$ Biochem 1988;103:302-8. 